\title{
Application of Marketing Mix Strategies and the Effect on Market Performance of Motor Vehicle Dealers in Kenya
}

\author{
Mercy Nkirote Githinji \\ MBA Candidate - School of Business \\ Jomo Kenyatta University - Nairobi, Kenya \\ Doris Mbugua \\ Lecturer -Jomo Kenyatta University -Nairobi, Kenya \\ Peter Maina Chege* \\ Senior lecturer -Kenyatta University -Nairobi, Kenya
}

\begin{abstract}
The environment in which organizations operate is constantly changing with different micro and macroeconomic factors influencing the organization's performance. Coping with the increasingly competitive environment has called on firms to rethink their marketing strategies. The need to respond to market changes on a daily basis, and the difficulty of predicting the direction of such changes means that organizations must strategically focus on their core competences and capabilities. The World Bank report (2015) clearly indicates that motor vehicles imports in Kenya have increased with $2.0 \%$ in the year 2015. However, this ratio keeps on changing depending on macro-economic factors such as increase or decrease on imports duty. Entry of new competitors into the market has caused a drastic change not only to the specific companies operations, but also to their products and services in the demanding market. The competition in the markets has created an attention for these companies to review their marketing strategies in order to remain relevant in the market. One of the determinant of performance is marketing mix focusing on the product, its price, its position and how well it is known by its customers. Studies show that application of marketing mix strategies influence the level of sales. However, minimal research exists on this relationship. Therefore, this study sought to establish the effect of marketing practices on market performance of Motor vehicle Dealers in Kenya. The study adopted four major practices namely; product strategies, price strategies, positioning strategies and promotion strategies and market performance as the dependent variable. Porters Five forces model, Resource based view model, stakeholders' theory and pricing theory were applied to explain the empirical literature. The study area was in Nairobi County, while target population of the study was the 7 major Dealers in cars. The study sampled at least one respondent from each management offices in the marketing department. Therefore, the study target a total of 21 respondents. Data was collected using self-administered questionnaires. Descriptive statistics such as frequencies, percentages, means and standard deviations will be used to analyse the data. A regression model was used to measure and explain the relationship of the study variables. The study concludes that the four strategies namely; product strategies, price strategies, positioning strategies and promotion strategies had a significant effect on performance. The study recommends that to achieve a high output, there is need to utilise all the four strategies as each has a specific contribution to the performance.
\end{abstract}

Keywords: Marketing mix, Product, Pricing, Positioning, Promotion, market performance, motor vehicle dealers DOI: $10.7176 / \mathrm{EJBM} / 11-27-06$

Publication date:September $30^{\text {th }} 2019$

\section{Introduction}

\subsection{Background information}

The ever dynamic environment requires players in the market place to be more efficient, this stresses the need to adapt a strategy in order to keep ahead of competitors (Muchiri, 2014). The environment in which organizations operate is constantly changing with different micro and macro-economic factors influencing the organizations. Since the turn of the millennium, the general business environment has become more volatile, unpredictable and very competitive. Coping with the increasingly competitive environment has called on firms to rethink their marketing strategies (Pearce \& Robinson, 2007). The days when firms could simply wait for clients to beat a path to their door are long gone. Organizations must realize that their services and products, regardless of how good they are, simply do not sell themselves (Kotler, 2001). The role of marketing in business organizations has not remained stable through time rather, it has evolved quite markedly, passing from a concentration on very specific aspects of business management to the use of decision-making models of great complexity. This process of change has taken place in parallel with an extension of the ambit in which marketing is studied and as a consequence of its interaction with other disciplines, such as planning or strategic management (Kimutai, 2015).

Several authors have reflected on the evolution in the adoption of the concept of marketing by firms. In fact, 
there is a clear parallelism in the approaches developed by these authors and one can note how the development of marketing activities has taken place in parallel with the needs of the firm (Muchiri, 2015). These needs have emerged simultaneously with the degree of rivalry that exists in the market and with the progressively more sophisticated tools employed in business management. In summary, these approaches illustrate the marked evolution experienced by the concept of marketing and its application in the business organizations, with ever greater importance being given to the strategic aspects and to the integrated character of marketing activities.

Strategy refers to the machinery of the resources and activities of an organization to the environment in which it operates (Johnson \& Scholes, 2002). According to Ansoff and McDonnell (1990), it is through strategic management that a firm will be able to position and relate itself to the environment to ensure its continued success and also secure itself from surprises brought about by the changing environment. A strategy of a corporation forms a comprehensive modern plan that states how the organization will achieve its mission and objectives, it maximizes competitive advantage and minimizes threats. Marketing as defined by the American Marketing Association (AMA, 2008) is the performance of business activities that direct the flow of goods and services from the producer to the ultimate consumer. Property, casualty and liability insurance marketing however not only includes the traditional marketing sales function but incorporates services such as customer needs analysis, market segmentation, product development and distribution that must be incorporated into a successful marketing mix (Kotler, 2003).

According to Kotler and Keller (2009), marketing strategies should include integrated marketing which means mixing and matching marketing activities to maximize their individual and collective efforts. It usually takes place on two levels. First, the various marketing functions-advertising, product management, marketing research and so on-must work together. Secondly, and marketing must be well coordinated with other company departments. That marketing does not work only when it is merely a department; it works only when all employees appreciate their impact on customer satisfaction. Coordinated marketing may only be executed successfully when the business executives of the organization understand the value of this notion and can make it work in the organization. The function of marketing strategy is to determine the nature, strength, direction and interaction between the marketing mix elements and the environmental factors in a particular situation. According to Levae (2006), the aim of developing an organization marketing strategy is to establish, build, defend and mention its competitive advantage.

According to Mavondo (2000), marketing strategy has been a salient focus of academic inquiry since the 1980s. However, the consensus is that strategic marketing practices provide the avenue for utilizing the resources of an organization in order to achieve its set goals and objectives. Generally, strategic marketing deals with the adapting of marketing mix-elements to environmental forces. It evolves from the interplay of the marketing mix elements and the environmental factors ( $\mathrm{Li}$ et al., 2000). Therefore, the function of strategic marketing practices is to determine the nature, strength, direction, and interaction between the marketing mix- elements and the environmental factors in a particular situation. According to Lavae (2006), the aim of the development of an organization's marketing strategy development is to establish, build, defend and maintain its competitive advantage.

According to Kerin and Peterson (2004), the concept of strategic marketing practices is essential to organizations in that it helps in; defining the organization's business, mission and goals; Identifying and framing organizations growth opportunities; formulating marketing strategies; budgeting, marketing, financial and production resources; and developing reformulation and recovery strategies. Adoption of strategic marketing practices helps Organizations to; formulate effective marketing objectives, formulate effective strategies on products, pricing, promotion, distribution, process and people, enable organizations to understanding their competitors in the industry and respond proactively rather than reactively (Kotler, 2005).

International marketing is becoming a major trend in modern business. To this effect, numerous studies concerning the consumer demand and purchase behavior for different products across national boundaries have been and are still being undertaken. According to Doole and Lowe (2008) international marketing is defined as the process of management responsibility in identifying, anticipating and satisfying customer requirements across international boundaries. Companies in developed nations like USA, European Nations have enbacked on strategic marketing practices for international trade (Kotler, 2005). A study carried out in Europe by Blumberg (2001) on application of marketing strategies by pharmaceutical companies clearly indicate that, marketing strategies are essential to any competitive company. The study further suggest that marketing mix strategies are adopted by firms as a means to survive.

According to Nagaraj (2008), the car market in India is increasing by leaps and bounds. The marketplace currently occupies a considerable share of the annual car production in India. Most players within the car industry are trying to outdo one another in terms of style, innovation, pricing, and technology, so as to achieve increased market share (Nagaraj, 2008). Also Internet is rapidly growing and providing the platform for ecommerce marketing, many customers use Internet partly or even fully, for all the buying process stages. Liu and Xuan (2008) discuss the various opportunities for car manufacturers and dealers to utilize the internet marketing 
medium in the five stages of e-marketing buying process - Problem Recognition, Information Search, Evaluation of Alternatives, Product Choice, Final Outcome / Post Purchase.

Kenya's automobile market is dominated by Toyota (East Africa), Cooper Motors Corporation (CMC), General Motors (GM), Simba Colt and DT Dobie, among others. At present, Japanese automaker Toyota makes up about 65 per cent of the market, primarily through second-hand dealerships. General motors East Africa Ltd is the largest motor vehicle assembler of Isuzu and Chevrolet brands in East and Central Africa and one of the leading Motor Vehicle distributors in Kenya. CMC Holdings, a publicly-listed Kenyan car manufacturer, has a large East African presence and exclusive distribution agreements for a range of heavy duty and high-end vehicles, including Land Rover, Volkswagen and the Nissan Diesel range of trucks. According to Kenya Motor Industry Association directory, there are 7 major registered Motor vehicle Dealers in Kenya. This include Toyota Kenya, cooper motor corporation, GM, Simba cold, DT dobie, RMA Motors and Beiben trucks.

\subsection{Problem statement}

The environment in which organizations operate is constantly changing with different factors influencing the organizations. Since the turn of the millennium, the general business environment has become more volatile, unpredictable and very competitive (Pearce \& Robinson, 2007). Coping with the increasingly competitive environment has called on firms to rethink their marketing strategies. The need to respond to market changes on a daily basis, and the difficulty of predicting the direction of such changes means that organizations must strategically focus on their core competences and capabilities (McIvor, 2008).

The Kenya Motor vehicle industry has become competitive than ever before. World Bank report (2015) clearly indicates that motor vehicles imports in Kenya have increased with $2.0 \%$ in the year 2014. However, this ratio keeps on changing depending on macro-economics factors such as increase or decrease on imports duty. Entry of new competitor into the market has cause a drastic change not only to the specific companies operations, but also to their products and services in the demanding market. The competition in the markets has created an attention for this companies to review their marketing strategies in order to remain relevant in the market. From the Kenya Motor Industry Association directory, there are 7 major registered Motor vehicle Dealers in Kenya. The PWC 2015 market report indicates that about $65 \%$ of the market is dominated by only one company (Toyota Kenya) while the rest share the remaining $35 \%$ of the market share. The issue of automobile industry market share in Kenya has been a point of discussion over the last two decades. Question being raised whether it is poor marketing strategies among the competitors or it an issue of consumer behaviour. Nevertheless every competitor in the Kenya market has tried to earn a share of the market through application of strategic marketing practices. Despite of the many marketing offer the new companies use to enter the market i.e. sales promotion, low pricing, new models among others, they still remain to be dormant in the market. The other few companies which have been reported to stir competition to Toyota Kenya which include, Subaru Dealers, Nissan, and land rover.

Several studies have been conducted both locally and internationally on strategic marketing. However no study have attempted to link the effect of strategic marketing practices on market performance of major Motor vehicle retailers in Kenya. Vassinen (2006) performed an extensive bibliometric study to examine which concepts have influenced most on strategic marketing discourse. He found those to be the competitive environment, operational marketing performance and international growth, the resource based view of a firm, and market orientation and performance. A study by Abdallah (2001) focused on an empirical investigation of the strategic marketing practices of the soft drink industry in Kenya. Obonyo (2013) evaluated marketing strategies adopted by supermarkets for competitive edge in Kisii town. In this study, findings indicated that the factors underlying the buying behaviour need be improved and that the majority who shop at supermarkets normally are middle class and upper class people. To improve the customer base, the supermarkets need to position themselves strategically, in terms of location and space. The most related studies to this research were that of Anyika (2007) which focused on the marketing strategies applied by the major motorcycle marketing firms in Kenya. The existing research has not statistically tested whether strategic marketing practices has effects on market performance of a firm. Different motor vehicle dealers sell different number of units per year. According to Kotler (2003), application of marketing mix strategies determines the level of sales. However, minimal research exists on this relationship. This study thus aimed to document on how application of marketing mix strategies affect the market performance of motor vehicle dealers in Kenya.

\subsection{Study objective}

1. To determine the effect of product strategies on market performance of Motor vehicle Dealers in Kenya.

2. To establish the effect of price strategies on market performance of Motor vehicle Dealers in Kenya.

3. To find out the effect of positioning strategies on market performance of Motor vehicle Dealers in Kenya.

4. To assess the effect of promotion strategies on market performance of Motor vehicle Dealers in Kenya. 


\subsection{Significance}

The study is based on the Motor vehicle Dealers in Kenya. The outcome of the study will be of great importance to managers on marketing strategies that would enhance the performance of their Organization both in external and internal environments. The study will enlighten the public on the marketing practices used by the motor vehicle companies. This information will be of high value to the potential vehicle buyers as it will help them make informed choices.

The study will be of great importance to policy makers and regulator in market. It will provide insight for fair completion practices which can be applied not only in the Motor vehicle industry but also in all other organization in the global market.

The study findings will add value to the existing body of information and literature. This will be used for future reference for the scholars and academicians who will be doing other studies related to the marketing practices in motor vehicle industry.

\subsection{Scope}

The study will focus on motor vehicle Dealers in Kenya. There are seven major Dealers in Kenya. The study will focus on the various managers in the marketing department. This managers are involved in making decision in terms of which product design, how much the product will cost, where to sell the product and how the products will be promoted in the market. The study will concentrate on four major variables which are product strategies, price strategies, position strategies and promotion strategies and how they affect market performance. The study will be carried out in a period of at least three months from September to November.

\subsection{Theoretical review}

A theory is a set of statements or principles devised to explain a group of facts or phenomena, especially one that has been repeatedly tested or is widely accepted and can be used to make predictions about natural phenomena. This study adopt three theories; Porter's five forces model, Ansoff strategies Model and pricing theory.

\subsection{Porter's five forces model}

Porter (1998) identifies five forces of competition as fierce rivalry, threat to entry, threat to substitutes, power of suppliers and power of buyers. He upholds that understanding the forces that shape a sectors competition is the basis for developing a strategy. Generic strategies can be effectively correlated to organizational performance by using key strategic practices. Porter posits that if the forces are extreme, no organization earns striking returns on investment and if the forces are benign, most of the companies are profitable. The composition of the five forces varies by industry and that an organization needs a separate strategy for every distinct industry such as the public universities. Porter's (1998) generic strategies comprise of low cost, differentiation, focus and combination strategies. These are commonly conventional as a strategic typology for all organizations.

Porter (2008) identifies five forces of competition as fierce rivalry, threat to entry, threat to substitutes, power of suppliers and power of buyers. He upholds that understanding the forces that shape a sectors competition is the basis for developing a strategy. Generic strategies can be effectively correlated to organizational performance by using key strategic practices. Porter posits that if the forces are extreme, no organization earns striking returns on investment and if the forces are benign, most of the companies are profitable. The composition of the five forces varies by industry and that an organization needs a separate strategy for every distinct industry such as the public universities. Porter's (1998) generic strategies comprise of low cost, differentiation, focus and combination strategies. These are commonly conventional as a strategic typology for all organizations.

Managers in the Airtel Company therefore can only develop and choose winning strategies by first identifying the competitive pressures that exists, measuring the virtual strength of each and gaining a profound understanding of the sector's whole competitive structure.

\subsection{Ansoff strategies model}

The product market matrix strategy by Ansoff (1987) allows for possible product mix scenarios. Ansoff (1998) felt that in developing strategy, it was essential to systematically anticipate future environmental challenges to an organization, and draw up appropriate strategic plans for responding to these challenges. Businesses develop through new/existing product and in existing or new markets. The Ansoff Matrix remains a popular tool for organizations that wish to understand the risk component of various growth strategies, including product versus market development, and diversification.

The Ansoff product/market matrix is a series of suggested growth strategies that set the direction for the business strategy. Market penetration is the name given to a growth strategy where the business focuses on selling existing products into existing markets in order to maintain or increase the market share of current products, secure dominance of growth markets, restructure a mature market by driving out competitors and 
increase usage by existing customers. Market development on the other hand is the name given to a growth strategy where the business seeks to sell its existing products into new markets. There are many possible ways of approaching this strategy, including new geographical markets, new product dimensions or packaging, new distribution channels and different pricing policies to attract different customers or create new market segments. Product development is the growth strategy where a business aims to introduce new products into existing markets. This strategy may require the development of new competencies and requires the business to develop modified products which can appeal to existing markets.

\subsection{Pricing theory}

There are two main different views on pricing in theory: economic view and marketing view. These two different views are put across by neoclassical economic thinking and behavioral pricing research respectively. The economic theory relates price to the supply and demand relationship while Cost, competition, and the price elasticity are key factors in determination of price. In competitive markets, the combined forces of competition and the desire of the sellers to maximize profits will bring supply and demand to an equilibrium point where price, marginal cost and average cost are equal (Kallianpur \& Karandikar, 2012; Png \& Wang, 2010). The theory on pricing recognize the fact that businesses may not be interested in profit alone but also in the extent of growth of their sales, market share, inventory position, liquidity, prestige, labour relations, among others and that the customer choice is influenced by a multiplicity of factors like his social standing, peer opinion, advertisements, shop displays.

\subsection{Conceptual framework Independent variable}

\section{Dependent variable}

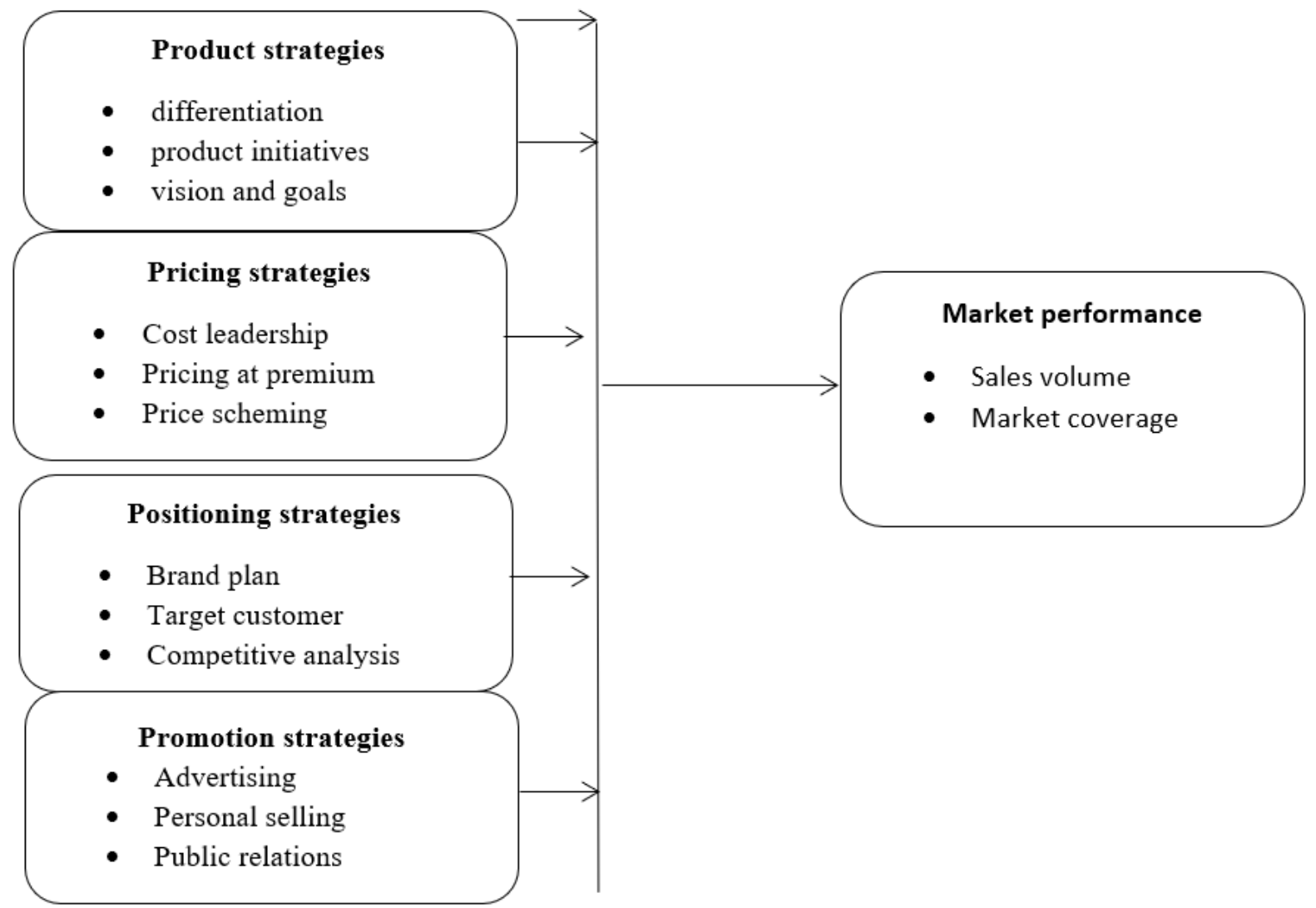

Figure 1. Conceptual framework

One variable is depends on or is a consequence of another variable, it is a dependent variable. The variable that is antecedent to the dependent or that makes it to change is called an independent variable. A conceptual framework consists of independent variables which causes changes in the dependent variable. The independent variables in this study include product strategy, pricing strategy, position strategy, promotion strategy. On the other hand, the dependent variable is market performance. 


\subsection{Empirical review}

\subsection{Product strategies}

A product as anything that can be offered to a market for attention, acquisition, use, or consumption that might satisfy a want or need. Consumers buy products frequently, with careful planning, and by comparing brands based on price, quality and style. According to Luan \& Sudhir (2010), the product is the core of the marketing mix strategy in which retailers can offer consumers symbolic and experiential attributes to differentiate products from competitors. However, it is also concerned with what the product means to the consumer. Product is about quality, design, features, brand name and sizes.

New product development one of the most important destabilizing tactics. For low-involvement products, consumers have more objective view of the nature of the attributes. The product is the core of the marketing mix strategy in which retailers can offer consumers symbolic and experiential attributes to differentiate products from competitors. Product strategy is about quality, design, features, brand name and sizes. Many attributes of a company's products, including brand name, quality, newness, and complexity, can affect consumer behaviour. The physical appearance of the product, packaging, and labelling information can also influence whether consumers notice a product in-store, examine it, and purchase it (Luan \& Sudhir, 2010)

Duncan (2005) argue that brand trust is created through brand messages that provide the benefits promised. The affective response overrides the cognitive under all experimental conditions in forming product-trial attitude.

\subsection{Pricing strategies}

A composite of pricing strategies as presented by $\mathrm{Wu}$ (2012) comprises of pricing strategies for new products and established products, flexible pricing strategies, product line-pricing strategy, bundling-pricing strategy and price-leader strategy. Different pricing strategies are recommended to fit with changes in marketing programs, market conditions, and product life cycles.

Dolgui and Proth (2010) describes pricing strategies as a tripod with costs to the provider, competition, and value to the customer as the three legs. He notes the need that the goal of an effective pricing strategy is manage revenues in ways that support firm's profitability. This requires a strategy that considers costs, competitors pricing and values created for the customers. To make a profit, a firm must set high prices enough to recover the full cost of producing and marketing the product or service, and a sufficient margin to yield the desired profit margin at the predicted sales volume.

A firm may set pricing strategies with an aim of maximizing profits and making as much money as possible. This goal has a problem of being seen as profiteering, high prices and monopoly. In both economic theory and business practice, however, there is nothing wrong with profit maximization. Theoretically if profits become high in an industry due to short supply in relation to demand, new capital will be attracted to increase production capacity which will increase supply and eventually reduce profits. Profiteering in the market place doesn't last long periods because substitutes become available, purchases can be postponed, and competition can increase to keep prices at reasonable level (Thanakornworakij et al., 2012).

\subsection{Positioning strategies}

To develop effective positioning strategies, managers need insights into how the various attributes of a service are valued by the current and prospective customers within that segment. An organization's service offering is successfully positioned if it has established and maintains a distinctive place for itself in the consumer's mind relative to competing organization's offerings. Positioning as defined by Kotlcr and Keller (2006) is "the act of designing the company's offering and image to occupy a distinctive place in the mind of the target market. The goal is to locate the brand in the minds of consumers to maximize the potential benefit of the firm". Positioning Strategy is a concept through which organizations concerned with the impact of their external environment on their strategic capability (resources and competences), and expectations and influence of stakeholders, Johnson and Scholes (2002). Many scholars have given positioning strategy different definition and meaning. They argued that positioning has been evolved from market segmentation, targeting and market structure.

The concept of competitive environment culminates in Porter's famous generic competitive strategies (1980) whereas Kotler's marketing concept (e.g. 1999; 2003) is used as a reference in operational marketing. Although terms "strategic marketing" and "marketing strategy" are very close to each considerably different phenomenon; marketing strategy is more about how to conduct operational marketing in long term (Kotler, 2003).

\subsection{Promotion strategies}

Promotion strategy involves the five elements of the promotion mix they include advertising, sales promotion, personal selling, public relations, and direct marketing (Allender, \& Richards, 2012). In order to keep up with the competition and changing consumer needs and wants, firms are forced to adopt effective promotional strategies to promote growth beyond boarders thus creating awareness and increasing usage rates of their products and services. Promotional strategies enable firms to attract and retain customers thus increased growth 
in terms of return on investments due to expanded client base (Kotler, 2003).

Promotion is a form of "non-personal presentation" as well as promotion of any kind of ideas, goods or services which are identified by the sponsor (Kotler, 2003). This form is quite cost effective in terms of dissemination of the messages. Promotion is not only applicable to the profit making organizations but also to the charitable organizations, the churches and the government agencies. According to Kotler (2003) promotion offers an opportunity in differentiating a brand. Promotion is one of the significant elements of marketing mix and it entails public relations, advertising, personal selling, and selling promotional components. Personal selling is the most facets of promotion strategies preferred by banks due to the current nature of the banking services

The focus on promotional efforts and development of marketing strategies has remained a challenge to many firms in Kenya. However, due to the growth of the service sector, it is necessary for any organizations to focus on promoting their services for them to survive in the dynamic business environment (Kotler, 2003). Today marketing of organizations manufacturing fast moving goods has remained a big challenge in Kenya. Since products can be separated from the person performing or selling them, it is the responsibility of both large and small organizations to adopt appropriate promotional strategies in order to attract and retain customers. Promoting fast moving goods using a diversity of communication channels promote attraction and retention of customers.

\subsection{Market performance}

Performance outcomes result from success or market position achieved (Hooley et al., 2001). Performance can be determined in various ways. It might stand for financial performance, market performance, customer performance or overall performance, the term business performance is mainly used as a general performance measure. Financial performance literally refers to financial measures, such as profit margin and return on investment (ROI). Market performance includes e.g. measures of market share and sales volume. Additionally, superior performance in this study refers to performance that exceeds that of its closest competitors (Hunt \& Morgan, 2001). Specially, superior market performance probably, but not necessarily, results in superior financial performance (Hooley et al., 2001).

Assessing marketing performance is an increasingly important but unfortunately difficult task for managers and other corporate stakeholders. The difficulty is apparent since marketing performance depends on external, largely uncontrollable actors, such as customer and competitors, as well as on internal measures of performance. To ease the complex situation at hand, several simplifications can be made.

Getting marketing function involved to important business decisions. There are two marketing performance assessment (MPA) systems, namely normative and contextual MPAs. The general structural model used in this study closely imitates the normative MPA system and stages of marketing performance process. These four stages are: (1) sources of advantage, or the resources and capabilities of the firm; (2) positional advantages, or the realized strategy of the firm concerning the value delivered to customers and the costs incurred by the firm relative to its competitors; (3) market performance outcomes, or customer and competitor responses to the firms' realized positional advantages; and (4) financial performance outcomes, that is, the costs and benefits to the firm of the achieved level of market performance (Morgan, Clark \& Gooner, 2002; Soliman, 2011).

\subsection{Research methodology 4.1 Research design}

A research design is the blue print of every research and outlines the procedure for collecting and analysing data. A research design is arrangement of the set condition for data collection and analysis. This arrangement is done in such a manner that its aims at combining relevance to the study with the economy in procedure. It defines the procedures to be used by the researcher during data analysis. Descriptive research design and census method will be applied in this research in attempting to describe and explain the influence of strategic marketing practices on performance of motor vehicle Dealers in Kenya, by using both primary and existing secondary data to fully describe the phenomenon. A census of the motor dealers will use qualitative and quantitative measures in order to answer the research question and thus arrive at the goal of the research.

\subsection{Population of the study}

The population of interest for the study consists of the major motor vehicle Dealers in Kenya. According to the Kenya Motor Vehicle Industry Association (KMIA) website, there were 39 major motor vehicle companies that are duly registered.

\subsection{Sampling and sampling techniques}

Through random sampling method the sample size will be determine. This technique is generally used in quantitative studies and random selection of sample enables you to confidently generalize results from all size of sample. 
The research target at least 3 personnel in the marketing department. This include the overall marketing manager, brand manager and sales and logistics manager. Which is equivalent to $30 \%$ of the entire population. The study selected $30 \%$ of the target population. Out of 156 questionnaires administered, only 117 were returned.

A sampling frame is the list of elements from which the sample may be drawn and be worked with operationally. The sampling frame for this study consisted of a list of all the Major motor vehicle Dealers in Kenya. However, the main respondent will be persons randomly select from the marketing manager, brand manager and sales and logistics manager offices in the all the companies. The total sample will be 156 respondents drawn from all the department from each dealers.

Table 1. Sample Size

\begin{tabular}{|l|l|l|l|}
\hline Management category & Number of dealers & Respondents per dealer & Sample size \\
\hline Marketing manager & 39 & 1 & 39 \\
\hline Brand manager & 39 & 1 & 39 \\
\hline Sales Manager & 39 & 1 & 39 \\
\hline Logistics manager & 39 & 1 & 39 \\
\hline Total & $\mathbf{1 5 6}$ & & $\mathbf{1 5 6}$ \\
\hline
\end{tabular}

\subsection{Data Collection instruments}

In this study, emphasis is given to primary sources. However some secondary data will be obtained using from the available reports and financial statements of various audit firm. The semi- structured interviews and use of questionnaire which will be administered to the respondents personally to shorten the response time and enable on the - spot clarification of any doubt that the respondents might have regarding any questions. The managers are responsible for strategic decision making and have access to resourceful information. Employees also will be involved adding more value to the data. Secondary data will be obtained from journals, web site of various firms and governing bodies, financial statement and annual reports.

\subsection{Data collection procedure}

Fourteen (14), questionnaires will be self-administered to the respondents through drop and pick by the researcher. The purpose of self-administering questionnaires to respondents is to establish rapport with the respondents while introducing the research, providing clarifications sought by the respondents on the spot and collecting the questionnaire immediately after they are completed.

Prior to data collection, an introduction letter authorizing data collection will be obtained from the School of Business, Jomo Kenyatta University of Agriculture and Technology. On the questionnaires, a request to answer all questions will be made to the respondents. The questionnaire composed of close ended questions for collection of primary data. The respondents will be required to complete questionnaire as honestly and as completely as possible. The respondents will be assured that strict confidentiality would be maintained in dealing with their identities. The completed questionnaires will be collected once they are filled out. However, before data collection, a pilot test will be conducted.

\subsection{Data analysis}

Anderson and Pole (2001), postulate that once data has been collected, the researcher must be able to interpret it reliably. The process involves summarizing and categorizing the data to a temporary manageable length, identify themes, analyze and assess. It is from this point that the researcher looked for meaning within the data and often related findings to previous studies to see if these support existing research. The data will be analyzed using descriptive statistics. Data is presented by use of cross tabulation charts and graphs, tables, percentages and frequencies to display a visual presentation of the data, for ease of understanding and analysis. The study has used multiple regression analysis to establish the relationship between the dependent and the independent variables.

\subsection{Results and discussion \\ 5.1 Demographic Information}

\subsubsection{Gender of the respondents}

From the results $78 \%$ of the respondents in the motor vehicle dealers market were Male. The number of female was $22 \%$ of the total respondents. As per the academic qualification of the respondents. $7 \%$ of the respondents had a diploma, $41 \%$ of the respondents had a degree, $34 \%$ of the respondents had a Masters degree and $12 \%$ of the respondents had a PhD. This is an indication of highly trained operators in the vehicle industry. The results shows further that all the respondents had sufficient academic background to answer the research questions.

\subsubsection{Years of work}

The results show $18 \%$ of the respondents had worked for the motor dealers for a duration of $0-2$ years, $42 \%$ for 3 to 5 years, $33 \%$ for 6 to 8 years and $8 \%$ for 9 years and above. The conclusion was that majority of the 
respondents had worked for the motor dealers for a period of 3 to 5 years. These finding means that many of the respondents had sufficient information about the company and thus were able to answer questions since they had worked for a period that was long enough.

\subsection{Descriptive statistics}

Table 2. Product strategies

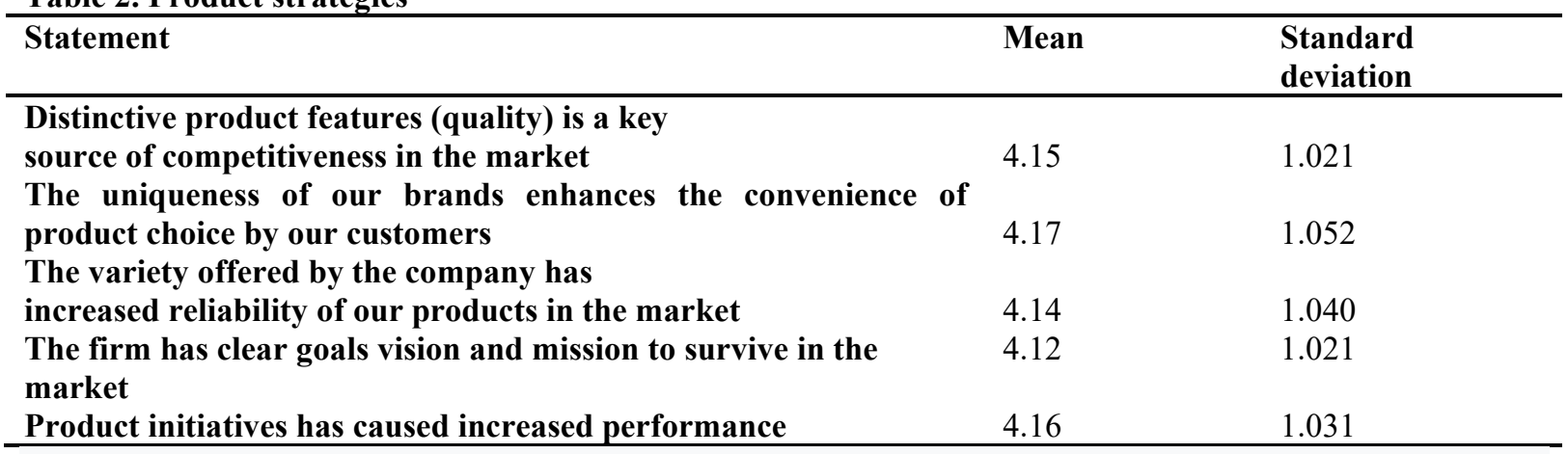

The study sought to examine the respondent's level of agreement or disagreement on the various measures of organizational leadership. Table 4.1, presents the relevant results which show that on a scale of 1 to 5 (where $1=$ strongly disagree and strongly agree $=5$ ) the means were found to be; distinctive product features (quality) is a key source of competitiveness in the market 4.15, the uniqueness of our brands enhances the convenience of product choice by our customers 4.17 , the variety offered by the company has increased reliability of our products in the market 4.14 , the firm has clear goals vision and mission to survive in the market 4.12 and product initiatives has caused increased performance 4.16. The interpretation was that product strategies adopted by the dealers led to better performance in the organization.

Table 3. Pricing strategies

\begin{tabular}{|l|l|l|}
\hline Statement & Mean & $\begin{array}{l}\text { Standard } \\
\text { deviation }\end{array}$ \\
\hline Total costs are kept lower compared to the competitors & 4.34 & 0.210 \\
\hline $\begin{array}{l}\text { The company uses blending as a price reducer strategy which determines } \\
\text { rate of return }\end{array}$ & 4.30 & 0.520 \\
\hline The company offers affordable goods and services to its customers & 4.29 & 0.400 \\
\hline The organization has a flexible pricing policy & 4.31 & 0.210 \\
\hline $\begin{array}{l}\text { The company has adopted pricing strategy as a means of competitive } \\
\text { advantage }\end{array}$ & 4.33 & 0.310 \\
\hline
\end{tabular}

The study sought to examine the respondent's level of agreement or disagreement on the various measures of pricing strategies. Table 4.6, presents the relevant results which show that on a scale of 1 to 5 the means; total costs are kept lower compared to the competitors 4.34, the company uses blending as a price reducer strategy which determines rate of return 4.30, the company offers affordable goods and services to its customers 4.29, the organization has a flexible pricing policy 4.31 , and the company has adopted pricing strategy as a means of competitive advantage 4.3 .

Table 4. Positioning strategies

\begin{tabular}{|l|l|l|}
\hline Statement & Mean & SD \\
\hline The company applies brand positioning to penetrate in the market & 4.05 & 0.041 \\
\hline The company applies pricing positioning to penetrate in the market & 4.07 & 0.012 \\
\hline The company uses target customer to position its vehicles in the market. & 4.07 & 0.020 \\
\hline The company position its products in the market based on the competitor product & 4.02 & 0.001 \\
\hline The company has adopted several strategies for positioning in the market & 4.01 & 0.061 \\
\hline
\end{tabular}

The study sought to examine the respondent's level of agreement or disagreement on the various measures of positioning strategy. Table 4.2, presents the relevant results which show that on a scale of 1 to 5 the means; the company applies brand positioning to penetrate in the market 4.05 , the company applies pricing positioning to penetrate in the market 4.07 , the company uses target customer to position its vehicles in the market 4.07 , the company position its products in the market based on the competitor product 4.02 and the company has adopted several strategies for positioning in the market 4.01 . 
Table 5. Promotion strategies

\begin{tabular}{|l|l|l|}
\hline Statement & Mean & SD \\
\hline Effective advertising has enhances brand awareness & 4.17 & 1.260 \\
\hline The company used personal selling for product promotion & 4.15 & 1.021 \\
\hline Promotion aims at presenting product information to consumers as well as others & 4.16 & 1.142 \\
\hline Promotion aims at increasing product demand & 4.11 & 1.212 \\
\hline Promotion aims at differentiating product offerings & 4.13 & 1.116 \\
\hline Offers are provided as a strategy of promoting company products in the market. & 4.09 & 1.214 \\
\hline
\end{tabular}

The study sought to examine the respondent's level of agreement or disagreement on the various measures of promotion strategies. Table 4.6, presents the relevant results which show that on a scale of 1 to 5 the means; effective advertising has enhances brand awareness 4.17, the company used personal selling for product promotion 4.15, promotion aims at presenting product information to consumers as well as others 4.16 , promotion aims at increasing product demand 4.11, promotion aims at differentiating product offerings 4.13 and offers are provided as a strategy of promoting company products in the market 4.09.

Table 6. Market Performance

\begin{tabular}{|l|l|l|}
\hline Statement & Mean & SD \\
\hline Strategic marketing practices have increased the sales volume of the company & 4.05 & 1.021 \\
\hline $\begin{array}{l}\text { The company market coverage extension is due to adoption of strategic marketing } \\
\text { practices }\end{array}$ & 4.09 & 1.052 \\
\hline The number of Customer complain have reduced in the market & 4.07 & 1.240 \\
\hline Our products are much preferred than those of competitors & 4.02 & 1.021 \\
\hline Sales volumes have increased over last three years & 4.06 & 1.031 \\
\hline The firm has grown in terms of market share & 4.04 & 1.040 \\
\hline Our sales revenue has been increasing & 4.02 & 1.161 \\
\hline The firm has experienced growth in profitability & 4.05 & 1.031 \\
\hline
\end{tabular}

The study sought to examine the respondent's level of agreement or disagreement on the various measures of market performance. Table 4.6, presents the relevant results which show that on a scale of 1 to 5 the means; strategic marketing practices have increased the sales volume of the company 4.05 , the company market coverage extension is due to adoption of strategic marketing practices 4.09 , the number of customer complain have reduced in the market 4.07 , our products are much preferred than those of competitors 4.02 , sales volumes have increased over last three years 4.06 , the firm has grown in terms of market share 4.04 , our sales revenue has been increasing 4.02 and the firm has experienced growth in profitability 4.05.

\subsection{Regression Results}

The fitted regression model is

$\mathrm{Y}=1.432+0.244 \mathrm{X}_{1}+0.206 \mathrm{X}_{2}+0.179 \mathrm{X}_{3}+0.234 \mathrm{X}_{4}+\varepsilon$

Where; $\mathrm{Y}=$ market performance, $\mathrm{X} 1$ = Product strategies, $\mathrm{X} 2=$ Pricing strategies, $\mathrm{X} 3$ = Position strategies, $\mathrm{X} 4=$ Promotion strategies, $\varepsilon=$ Error Term.

\subsubsection{Product strategies}

From table 4.12 the regression coefficient of Product strategies was found to be 0.244 . This value shows that holding other variables in the model constant, an increase in Product strategies by one unit causes the market performance to increase by 0.244 units. The value of the coefficient is also positive. The positive effect shows that there is a positive relationship between Product strategies and market performance.

The coefficient was also statistically significant with a t-statistic value of 5.810 . The t-statistic $p$-value was found to be 0.000 . This therefore shows that increase or adoption of product strategies leads to improved market performance. Lai et al. (2010) found a significant correlation between performance of the product and reputation of companies. Product strategies had effect on market performance. The interpretation was that Product strategies causes the market performance to increase. The motor vehicle dealers should consider the effect of Product strategies to their market performance.

\subsubsection{Pricing strategies}

From table 4.12 the regression coefficient of pricing strategies was found to be 0.309 . This value shows that holding other variables in the model constant, an increase in pricing strategies by one unit causes the market performance to increase by 0.309 units. The value of the coefficient is also positive. The positive effect shows that there is a positive relationship between pricing strategies and market performance.

The coefficient was also statistically significant with a t-statistic value of 9.008 . The t-statistic p-value was found to be $<0.001$. This therefore shows that increase or adoption of pricing strategies pricing strategies leads to improved market performance. Lau, et al. (2012), argue that, price changes have inverse relationship with sales (demand) for a normal good and other things assumed. Pricing include: discount, allowance and credit. There is 
also a positive relation between suitable prices with customer loyalty. The interpretation was that pricing strategies causes the market performance to increase. The motor vehicle dealers should consider the effect of pricing strategies to their market performance.

\subsubsection{Position strategies}

From table 4.12 the regression coefficient of Position strategies was found to be 0.186 . This value shows that holding other variables in the model constant, an increase in Position strategies by one unit causes the market performance to increase by 0.186 units. The value of the coefficient is also positive. The positive effect shows that there is a positive relationship between position strategies and market performance.

The coefficient was also statistically significant with a t-statistic value of 4.537 . The t-statistic p-value was found to be 0.000 . This therefore shows that increase or adoption of Position strategies leads to improved market performance. Klinkerman (2003) argue that positioning must establish a position for the product firm in the customers mind should be distinctive providing one simple consistent message and must set the product/firm apart from competitors. The interpretation was that position strategies causes the market performance to increase. The motor vehicle dealers should consider the effect of Product strategies to their market performance.

\subsubsection{Promotion strategies}

From table 4.12 the regression coefficient of promotion strategies was found to be 0.235 . This value shows that holding other variables in the model constant, an increase in product strategies promotion strategies by one unit causes the market performance to increase by 0.235 units. The value of the coefficient is also positive. The positive effect shows that there is a positive relationship between Promotion strategies and market performance.

The coefficient was also statistically significant with a t-statistic value of 7.581 . The t-statistic $p$-value was found to be $<0.001$. This therefore shows that increase or adoption of Promotion strategies leads to improved market performance. These finding support those of Brassington and Pettitt (2005) who found that Promotion strategies had effect on market performance. According to Brassington and Pettitt (2005) the direct way in which an organization communicates the product or service to its target audiences is through promotion. The interpretation was that Promotion strategies cause the market performance to increase. The motor vehicle dealers should consider the effect of Promotion strategies to their market performance.

Results suggests that there is a strong relationship between, Product strategies, Pricing strategies, Position strategies, Promotion strategies and market performance. This indicates that Product strategies, Pricing strategies, Position strategies, Promotion strategies causes a variation of $87.2 \%$ on market performance. The conclusion is that the four variables used only explains $87.2 \%$ of the variation on the variation on dependent variable. This suggest that all the four variables; product strategies, pricing strategies, position strategies, promotion strategies were relevant in explaining the market performance.

\subsection{Conclusion and recommendation 6.1 Conclusion}

The study conclude that distinctive product features (quality) is a key source of competitiveness in the market, the uniqueness of firms brands enhances the convenience of product choice by the customers, the variety of products offered by the company has increased reliability of our products in the export market, the firm has clear goals vision and mission to survive in the market and product initiatives has caused increased performance.

The study also shows that pricing strategies can have significant effect on market performance of motor dealers companies in the Country. In particular the study found that if the total costs are kept lower compared to the competitors, the company uses blending as a price reducer strategy which determines rate of return, the company offers affordable goods and services to its customers, the organization has a flexible pricing policy and the company has adopted pricing strategy as a means of competitive advantage would cause the performance to go up.

The study also shows that positioning strategies can have significant effect on market performance of motor dealers companies in the Country. In particular the study found that if the company applies brand positioning to penetrate in the market, the company applies pricing positioning to penetrate in the market, the company uses target customer to position its vehicles in the market, the company position its products in the market based on the competitor product and the company has adopted several strategies for positioning in the market would cause the performance to go up.

Promotion: The study also shows that promotion strategies can have significant effect on market performance of motor dealers companies in the Country. In particular the study found that if effective advertising has enhances brand awareness, the company used personal selling for product promotion, promotion aims at presenting product information to consumers as well as others, promotion aims at increasing product demand, promotion aims at differentiating product offerings and offers are provided as a strategy of promoting company products in the market would cause the performance to go up. 


\subsection{Recommendations}

There should also be an establishment of good marketing strategies that ensure that the motor dealers can do better in the industry. In particular the companies should make sure that good Product strategies are adopted. In this case the firms should make sure that their products are of high quality compared to other players in the region. This means that the product should be appealing to the customers and also meets the customers' desires and specification.

The firms should also have good Pricing strategies. The pricing of the products should be aligned to the economic capabilities of the clients. Prices should also reflect the utility derived from their products. The other key pillar of marketing strategies considered is the Position strategies. The positioning strategy deals with the place of the product in the market. The firms should also be keen on positioning there products in the market. The final key aspect of marketing strategy is the Promotion strategies. Promotion strategies entails the strategies used by the firm to make the public or the potential clients aware of their products. This ensures that the client get the first hand information from the firms and thus get more confidence about the product that they intend to purchase.

\section{References}

Abdallah, H. K. (2001). An Empirical Investigation of the Strategic Marketing Practices of the Soft Drink Industry in Kenya, unpublished Research Thesis, University of Nairobi

Allender, W. J., \& Richards, T. J. (2012). Brand loyalty and price promotion strategies: an empirical analysis. Journal of Retailing, 88(3), 323-342.

American Marketing Association. (2008). Definition of Marketing and Expected Product Quality, Journal of Consumer Research, 16 (December), 344-353.

Anderson, M. J. (2001). A new method for non-parametric multivariate analysis of variance. Austral ecology, 26(1), 32-46.

Ansoff, H. I. (1987). The concept of corporate strategy. Homewood, IL: Irwin.

Ansoff, H. I., Declerck, R. P., \& Hayes, R. L. (1990). From strategic planning to strategic management. In Strategische Unternehmungsplanung/Strategische Unternehmungsführung(pp. 110-147). Physica, Heidelberg.

Anyika D. (2007) Marketing Strategies Applied By The Major Motorcycle Marketing Firms In Kenya, Unpublished Research Thesis, University of Nairobi

Blumberg, B. F. (2001). Cooperation contracts between embedded firms. Organization studies, 22(5), 825-852.

Brassington, F., \& Pettitt, S. (2005). Principles of marketing. London, NY: FT Prentice Hall.

Dolgui, A., \& Proth, J. M. (2010). Pricing strategies and models. Annual Reviews in Control, 34(1), 101-110.

Doole, I., \& Lowe, R. (2008). International marketing strategy: analysis, development and implementation. Cengage Learning EMEA.

Duncan, Tom (2005), Principles of advertising \& IMC (2nd Ed.). New York: McGraw-Hill.

Hooley, G., \& Greenley, G. (2005). The Resource Underpinnings of Competitive Positions. Journal of Strategic Marketing, 13(2), 93-116.

Hult, T., Hurley, R., Knight, G. (2004), Innovativeness: its antecedents and impact on business performance, Industrial Marketing Management, Vol. 33 pp.429-38.

Kallianpur, G., \& Karandikar, R. L. (2012). Introduction to option pricing theory. Springer Science \& Business Media.

Kimutai, J. J. (2015). Influence of strategic marketing practices on performance of firms in the flower industry in Kenya.

Kimani P.K. (2002). Product Strategy In The Marketing Of Financial Services. A Survey of the Commercial Banking Sector in Kenya, unpublished Research Thesis, University of Nairobi

Klinkerman, S. (2003). The management factor. Banking Strategies, 79(5), 48-48.

Kotler, P., \& Caslione, J. A. (2009). How marketers can respond to recession and turbulence. Journal of Customer Behaviour, 8(2), 187-191.

Kotler, P. (2003). Marketing management (11th Ed.).Prentice Hall.

Kotler. P. \& Keller, K.K. (2006). Marketing Management (12th ed.). New Jersey: Prentice Hall International.

Kotler, P., \& Zaltman, G. (2001). Targeting prospects for a new product. Marketing: Critical Perspectives on Business and Management, 4(1), 328.

Lai, C. S., Chiu, C. J., Yang, C. F., \& Pai, D. C. (2010). The effects of corporate social responsibility on brand performance: The mediating effect of industrial brand equity and corporate reputation. Journal of business ethics, 95(3), 457-469.

Lau, H. S., Su, C., Wang, Y. Y., \& Hua, Z. S. (2012). Volume discounting coordinates a supply chain effectively when demand is sensitive to both price and sales effort. Computers \& Operations Research, 39(12), 32673280 . 
Lavie, D. (2006). Capability Reconfiguration: An Analysis of Incumbent Responses to Technology Change. Academy of Management Executive, 31(1):153-174.

Li, S., Kinman, R., Duan, Y., \& Edwards, J.S., (2000).Computer-Based Support for Marketing Strategy Development. European Journal of Marketing, 34(5/6).

Liu, Y., Li, Y., Tao, L., \& Wang, Y. (2008). Relationship stability, trust and relational risk in marketing channels: Evidence from China. Industrial Marketing Management, 37(4), 432-446.

Luan, Y. J., \& Sudhir, K. (2010). Forecasting marketing-mix responsiveness for new products. Journal of Marketing Research, 47(3), 444-457.

Muchiri. D, (2014) Competitive strategies adopted by motor vehicle parts manufacturing firmsin Kenya, Unpublished Research Thesis, University of Nairobi

Nagaraj, R. (2008). India's recent economic growth: a closer look. Economic and Political Weekly, 55-61.

Obonyo, G. O. (2013). Evaluating marketing strategies adopted by supermarkets for competitive edge: A case of Kisii town supermarkets. A B.Ed. research report submitted in Jomo Kenyatta University of Agriculture and Technology.

Oyedijo, A., Idris, A. A., \& Aliu, A. A. (2012). Impact of marketing practices on the performance of small business enterprises: empirical evidence from Nigeria. European Journal of Economics, Finance and Administrative Sciences, 46, 130-46.

Pearce and Robinson (1997)"Strategic management-formulation, implementation and contro "Sixth Edition, Mc Graw Hill, London.

Png, I. P., \& Wang, H. (2010). Buyer uncertainty and two-part pricing: theory and applications. Management Science, 56(2), 334-342.

Porter, Michael E.1998.Competitive Strategy: techniques for analysing industries and companies-with a new introduction. Free Press

Schroder, B., \& Mavondo, F. (2000). Marketing orientation, interfirm relationships and the resource-based theory of the firm: towards an integrative theory. In Advances in International Marketing (pp. 29-44). JAI Press.

Soliman, H. S. (2011). Customer relationship management and its relationship to the marketing performance. International journal of business and social science, 2(10).

Terry, C., \& Kerin, R. A. (2004). Book Review: Reflections of a Marketing Educator with Scholarly Ambitions.

Thanakornworakij, T., Nassar, R., Leangsuksun, C. B., \& Paun, M. (2012, August). An economic model for maximizing profit of a cloud service provider. In 2012 Seventh International Conference on Availability, Reliability and Security (pp. 274-279). IEEE.

Vassinen, A. (2006). The Concept of Strategic Marketing in Marketing Discourse-A Bibliometric Study. Helsinki University of Technology Department of Industrial Engineering and Management, Institute of Strategy and International Business, Master's Thesis, Helsinki.

$\mathrm{Wu}$, C. H. (2012). Product-design and pricing strategies with remanufacturing. European Journal of Operational Research, 222(2), 204-215. 